\title{
PERANCANGAN SISTEM INFORMASI REKAM MEDIS ELEKTRONIK RAWAT JALAN BERBASIS WEB DI KLINIK GIGI BRIGHT SMILES BALI
}

\author{
Dewa Made Andika Dwi Prawiradirjo ${ }^{1)}$ Bambang Hadi Kartiko $^{2)}$ Gerson Feoh $^{3)}$ \\ Program Studi Perekam Dan Informasi Kesehatan ${ }^{1) 2}$ \\ Program Studi Teknik Informatika ${ }^{3)}$ \\ Fakultas Ilmu Kesehatan Sains dan Teknologi, Universitas Dhyana Pura, Badung, Bali ${ }^{1{ }^{12}}$ ) 3) \\ dwiprawira13@gmail.com ${ }^{(1)}$ bambanghadikartiko@undhirabali.ac.id ${ }^{2)}$ gerson.feoh@undhirabali.ac.id ${ }^{3)}$

\begin{abstract}
The medical record officer at Bright Smiles Bali Clinic is still having difficulty in the process of managing the data of outpatients because the clinic still using manual system that has not been computerized. So it is necessary to design a web-based electronic medical record information system that can help medical record officer in patient data management process. The method used in the design of this system is the system development life cycle (SDLC) which consists of the planning, analysis, design, implementation, and usage phases. The purpose and benefits of this information system design is to produce a web based outpatient medical record information system at Bright Smiles Bali Clinic.This information system facilitate medical record officer in carrying out patient data management covering patient registration process, recording of patient medical record, doctors data recording, code search on ICD 9 CM, code search on ICD 10. Besides, this information system produces various reports as well as patient medical record information that management needs for decision making.
\end{abstract}

Keywords: Information System, Electronic Medical Record, Outpatient, Web.

\begin{abstract}
ABSTRAK
Petugas rekam medis di Klinik Gigi Bright Smiles Bali masih kesulitan dalam proses pengelolaan data pasien rawat jalan karena masih menggunakan sistem manual yang belum terkomputerisasi. Maka diperlukan sebuah sistem informasi rekam medis elektronik berbasis web yang dapat membantu petugas rekam medis dalam proses pengelolaan data pasien tersebut. Metode perancangan sistem ini menggunakan siklus hidup pengembangan sistem (Systems Development Life Cycle-SDLC) yang terdiri dari tahap perencanaan, analisis, desain, implementasi, dan penggunaan. Sedangkan tujuan dan manfaat dari perancangan sistem informasi ini yaitu menghasilkan sistem informasi rekam medis elektronik rawat jalan berbasis web di Klinik Gigi Bright Smiles Bali. Dengan adanya sistem informasi ini, dapat memudahkan petugas rekam medis dalam pengelolaan data pasien yang meliputi proses pendaftaran pasien, pencatatan rekam medis pasien rawat jalan, pencatatan data dokter, pencarian kode ICD $9 \mathrm{CM}$, pencarian kode ICD 10. Selain itu sistem informasi ini menghasilkan berbagai laporanlaporan serta informasi rekam medis pasien yang dibutuhkan pihak manajemen untuk pengambilan keputusan.

Kata Kunci : Sistem Informasi, Rekam Medis Elektronik, Rawat Jalan, Web.
\end{abstract}




\section{PENDAHULUAN}

Seiring dengan perkembangan teknologi informasi dan komunikasi yang telah berpengaruh besar bagi perubahan pada semua bidang, termasuk bidang kesehatan khususnya pada proses rekam medis yang disebut dengan rekam medis elektronik (Hozinah, 2010). Klinik Gigi Bright Smiles Bali yaitu klinik yang berlokasi di Jalan Nangka Selatan No. 105 Denpasar, Bali. Dalam pelayanan yang diberikan masih secara manual dengan menulis data pasien di formulir pendaftaran, ini akan membutuhkan waktu 5-8 menit. Permasalahan lain yang ada di klinik yaitu penyimpanan rekam medis rekam pasien rawat jalan dan data lainya ini tersimpan didalam buku besar, sehingga pada proses pencarian data pasien akan membutuhkan waktu 5-10 menit dan data yang dicari tidak ditemukan, untuk pembuatan laporan perbulan dilakukan perekapan dan menghitung kembali transaksi setiap pasien. Pada saat merekap dan menghitung kembali setiap transaksi, bukan tidak mungkin ada data yang salah dan perhitungan harus berulang kali untuk meyakinkan bahwa perhitungannya sudah benar. Sehingga diperlukan adanya rancangan pengembangan sistem dengan tingkat perhitungan dan penyampaian datanya lebih cepat menjadi 2-3 menit, mampu bekerja cepat dan lebih akurat, sehingga dapat mempercepat dan mempermudah proses pengelolaan data pasien.

\section{TINJAUAN PUSTAKA \\ Pngertian Klinik}

Klinik adalah fasilitas pelayanan kesehatan yang menyelenggarakan pelayanan kesehatan perorangan yang menyediakan pelayanan medis dasar dan/atau spesialistik. Tenaga Kesehatan adalah setiap orang yang mengabdikan diri dalam bidang kesehatan serta memiliki pengetahuan dan/atau keterampilan melalui ilmu pendidikan di bidang kesehatan yang untuk jenis tertentu memerlukan kewenangan untuk melakukan upaya kesehatan. Setiap tenaga kesehatan lain yang bekerja di Klinik harus mempunyai Surat Tanda Registrasi (STR), dan Surat Izin Kerja (SIK) atau Surat Izin Praktik (SIP) sesuai ketentuan peraturan pada (Permenkes No.9/Menkes/Per/I/2014).

\section{Rekam Medis}

Rekam medis adalah keterangan baik yang tertulis maupun yang terekam tentang identitas, anamnesis, penentuan fisik, laboratorium, diagnosa segala pelayanan dan tindakan medik yang diberikan kepada pasien dan pengobatan baik yang di rawat inap, rawat jalan, maupun yang mendapat pelayanan gawat darurat (Depkes, 2006).

\section{Sistem Informasi Kesehatan (SIK)}

Sistem informasi kesehatan (SIK) merupakan suatu Sistem Informasi yang terdiri dari data, manusia, dan proses, serta kombinasi dari perangkat keras, perangkat lunak dan teknologi komunikasi atau yang dikenal dengan teknologi informasi. Penggunaan sistem informasi terlibat dalam tiga tahap yaitu pemasukan data, pemrosesan, dan pengeluaran informasi. Tahap pemasukan data menggunakan formulir data atau lembar data yang bisa jadi belum memiliki arti. Maka sistem kemudian akan mengolah data ini menjadi informasi yang lebih berarti (Hatta, 2013).

\section{Sistem Informasi Rekam Medis}

Sistem informasi rekam medis atau disebut dengan virtual patien record atau elektronic medical record ini digunakan untuk mengelola informasi rekam medis, sehingga memudahkan dalam melakukan penelusuran informasi, termasuk sejarah penyakit dan tindakan medis yang pernah diterima pasien, dan nantinya dengan adanya sistem rekam medis elektronik (RKE), seorang tenaga medis dapat mengambil suatu tindakan medis secara tepat. Secara garis besar sistem informasi rekam medis memungkinkan pengguna dapat melakukan pengisian, penyimpanan, memanggil ulang, mentransmisikan dan memanipulasi / mengolah data pasien secara spesifik baik perindividu atau kelompok, termasuk data klinis, administrasi dan demografi, sehingga dapat mengurangi pembiayaan operasional rumah sakit (Rustiyanto, 2010). 
Rekam Kesehatan Elektronik

Rekam kesehatan elektronik atau electronic medical record juga sering disebut dengan computer based patient record (CPR) untuk menyatakan suatu sistem berbasis komputer yang dimanfaatkan untuk mengelola informasi pelayanan pasien.

\section{Database (Basis Data)}

Secara umum, database berarti koleksi data yang selalu terkait. Secara praktis, basisi data dapat dianggap sebagai suatu penyusunan data yang terstruktur yang disimpan dala media pengingat ( harddisk) yang tujuannya adalah agar data tersebut dapat diakses dengan mudah dan cepat. Ada beberapa macam database, antara lain database hirarki, database jaringan, dan database relasional. Database relasional merupakan database yang populer saat ini dan telah diterapkan pada berbagai platform, dari PC hingga mini komputer (Kadir, 2003).

\section{Web}

World Wide Web atau www atau juga dikenal dengan web adalah salah satu layanan yang didapat oleh pemakai komputer yang terhubung ke internet. Web ini menyediakan informasi bagi pemakai komputer yang terhubung ke internet. Website atau situs dapat diartikan sebagai kumpulan halaman-halaman yang digunakan untuk menampilkan informasi teks, gambar diam atau gerak, animasi, suara, dan atau gabungan dari semuanya itu baik yang bersifat statis maupun dinamis yang membentuk satu rangkaian bangunan yang saling terkait dimana masing-masing dihubungkan dengan jaringan-jaringan halaman (hyperlink). Website atau situs juga diartikan sebagai kumpulan halaman-halaman yang digunakan untuk menampilkan informasi teks, gambar diam atau gerak, animasi, suara, dan atau gabungan dari semuanya, baik yang bersifat statis maupun dinamis yang membentuk satu rangkaian bangunan yang saling terkait, yang masing-masing dihubungkan dengan jaringan-jaringan halaman (Feoh, et al., 2015).

\section{Browser}

Browser merupakan sebuah program yang digunakan untuk menampilkan halaman web. Browser dirancang untuk mengambil informasi-infrmasi dari suatu server computer pada jaringan internet. Untuk mengakses web diperlukan program yaitu web browser (Sutarman, 2007).

\section{XАMPP}

XAMPP merupakan paket PHP dan MySQL berbasis open source, yang dapat digunakan sebagai tool pembantu pengembangan aplikasi berbasis PHP. XAMPP mengombinasikan beberapa paket perangkat lunak berbeda ke dalam satu paket. Memanfaatkan XAMPP sebagai database karena XAMPP menyediakan aplikasi database MySQL dengan interface lebih mudah dalam pengoperasiannya, tool-tool yang disediakan cukup lengkap dan memenuhi kebutuhan perancangan database selain itu XAMPP aplikasi gratis (Choliviana, et al., 2012).

\section{HTML(Hypertext Markup Language)}

HyperText Markup Language (HTML) adalah suatu sistem untuk menambahkan dokumen dengan tabel yang menandakan bagaimana teks di dokumen harus disajikan dan bagaimana dokumen duhubungkan bersamasama. Di dalam skema tambahan HTML terdapat kekuatan untuk membuat aplikasiaplikasi client-server, multimedia, form, dan interaktif. HTML sebenarnya adalah dokumen ASCII atau teks biasa, yang dirancang untuk tidak tergantung pada suatu sistem operasi tertentu. Secara teknis, HTML didefinisikan sebagai Standard Generalized Markup Language (SGML). Sebuah dokumen HTML dapat dikatakan contoh sebuah dokumen SGML. SGML berasal dari GML (General Markup Language) pada IBM di akhir tahun 1960-an sebagai upaya untuk memecahkan beberapa problem mengangkut dokumendokumen pada sistem komputer yang berbeda (Feoh, et al., 2015). 


\section{PHP (Perl Hypertext Preprocessor)} Perl Hypertext Preprocessor (PHP) merupakan skrip yang bersifat server site dimana proses pengerjaan skripnya berlangsung di server. Dengan menggunkan PHP maka perawatan suatu situs $W e b$ akan menjadi lebih mudah. PHP pertama kali ditemukan oleh Rasmus Lerdoff. Penulisan skrip PHP tersebut dengan cara disisipkan pada HTML. PHP merupakan bahasa pemrograman yang digunakan untuk membangun aplikasi-aplikasi berbasis Web khususnya aplikasi $\mathrm{Web}$ yang bersifat dinamis (Feoh, et al., 2015).

\section{MySQL}

MySQL merupakan sebuah basis data yang mengandung satu atau beberapa kolom. Tabel terdiri atas sejumlah basis dan setiap baris mengandung satu atau beberapa kolom. Didalam PHP telah menyediakan fungsi untuk koneksi ke basis data dengan sejumlah fungsi untuk pengaturan baik menghubungkan maupun memutuskan koneksi server database MySQL sebagai sarana untuk mengumpulkan informasi (Kustiyahningsih, et al., 2011).

\section{DFD (Data Flow Diagram)}

DFD merupakan alat yang dipakai dalam perancangan sistem terstruktur. Alat ini menggambarakan secara grafis aliran data pada sistem. DFD sering juga disebut DAD (Diagram Aliran Data). Merupakan representasi grafik yang menggambarkan aliran informasi dan transformasi informasi yang diaplikasikan sebagai data yang mengalir dari masukan (input) dan keluaran (output) (Supardi, 2013).

\section{ERD (Entity Relationship Diagram)}

Pada Model Entity-Relational, semesta data yang ada di dunia nyata diterjemahkan dengan memanfaatkan sejumlah perangkat konseptual menjadi sebuah diagram data, yang umumnya disebut sebagai Diagram Entity Relationship ( Diagram E-R).

\section{METODE PENELITIAN Kerangka Berpikir}

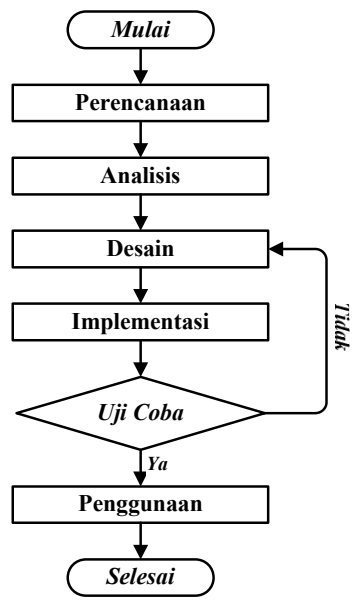

Gambar 1. Kerangka Berpikir

\section{Metode Penelitian}

Metode penelitian yang digunakan untuk Perancangan Sistem Informasi Rekam Medis Elektronik Rawat Jalan Bebasis Web di Klinik Gigi Bright Smiles Bali adalah siklus hidup pengembangan sistem SDLC (Systems Development Life Cycle) atau sering kali disebut sebagai pendekatan air terjun (waterfall approach) Secara garis besar besar metode waterfall mempunyai langkah-langkah sebagai berikut : Analisa, desain, penulisan, pengujian dan penerapan serta pemeliharaan (Kadir, 2003).

\section{Teknik Pengumpulan Data}

Adapun jenis pengumpulan data yang digunakan dalam penelitian ini sebagai berikut :

1. Wawancara (Interview)

2. Studi Pustaka (Literature)

\section{Tahap Perencanaan}

Adanya sistem informasi rekam medis elektronik rawat jalan berbasis web ini dapat memudahkan pekerjaan petugas rekam medis dalam mengelola rekam medis dari pendaftaran sampai pelaporan, sehingga data menjadi lebih akurat, dan dokter juga akan terbantu dalam melihat rekam medis pasien untuk bisa melakukan pelayanan yang optimal. 


\section{Analisis Kebutuhan Perangkat Keras}

Perangkat keras yang dibutuhkan dalam Perancangan Sistem Informasi Rekam Medis Elektronik Rawat Jalan Bebasis Web di Klinik Gigi Bright Smiles Bali, terdiri dari:

- Processor Intel Pentium IV 1,6 Ghz.

- Memory $512 \mathrm{MB}$.

- Harddisk 80 GB.

- Layar monitor Vga $128 \mathrm{MB}$.

- Mouse dan keyboard sebagai piranti input.

- Printer sebagai piranti output.

\section{Analisis Kebutuhan Perangkat Lunak}

Perangkat lunak yang dibutuhkan dalam Perancangan Sistem Informasi Rekam Medis Elektronik Rawat Jalan Bebasis Web di Klinik Gigi Bright Smiles Bali, terdiri dari:

- Microsoft Windows (XP, Vista, 7, 8, 8.1).

- Web browser (Chrome, Mozilla Firefox, Opera).

- XAMPP sebagai server yang berdiri sendiri (localhost).

- MySql sebagai database server dan Apache sebagai web server.

- Adobe Dreamweaver CS6 sebagai editor web.

- PHP, HTML, CSS, dan JavaScrib sebagai bahasa pemograman web.

\section{Desain Sistem}

Perancangan yang menggunakan model Data Flow Diagram (DFD) atau diagram aliran data (DAD) adalah untuk mengilustrasikan bagaimana data mengalir melalui proses-proses yang saling tersambung pada Perancangan Sistem Informasi Rekam Medis Elektronik Rawat Jalan Berbasis Web di Klinik Gigi Bright Smiles Bali.

\section{Diagram Konteks}

Diagram konteks merupakan diagram paling atas dari sistem informasi yang menggambarkan proses-proses yang terjadi pada sistem dalam bentuk diagram alir data (DAD). Untuk menyediakan berbagai informasi akan dijelaskan tahapan-tahapan proses melalui penggambaran diagram konteks, yaitu:

\section{Diagram Konteks}

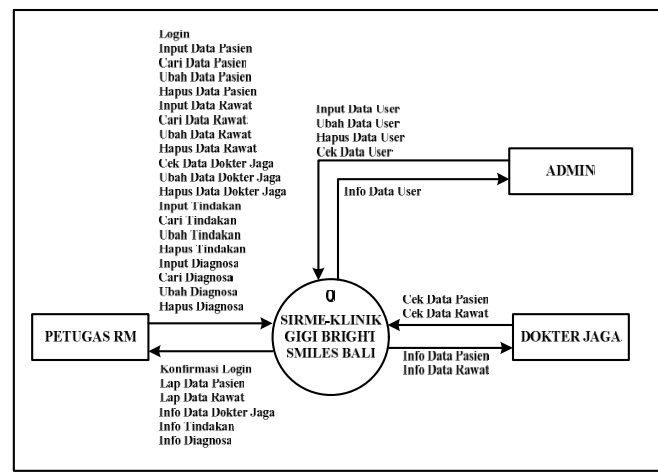

Gambar 2. Diagram Konteks

\section{DFD Level 0}

DFD Level 0 Menggambarkan beberapa proses aliran-aliran data yang masuk dan keluar ke database. DFD Level 0 Perancangan Sistem Informasi Rekam Medis Elektronik Rawat Jalan dapat dilihat pada gambar berikut :

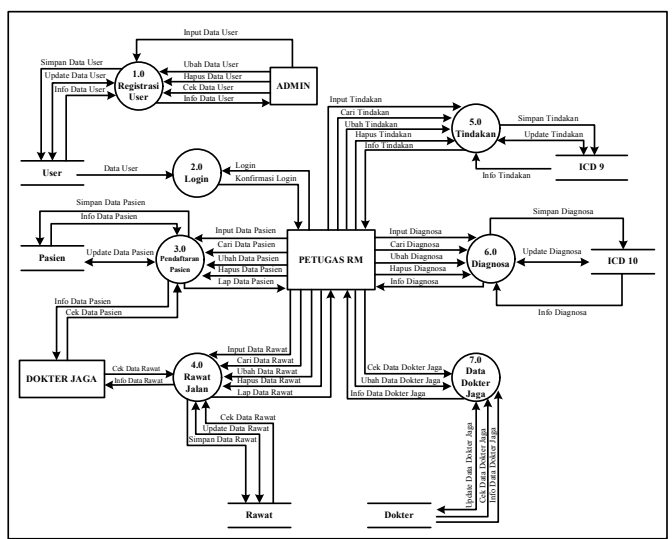

Gambar 3. DFD Level 0

Beberapa proses pengolahan data perancangan sistem informasi rekam medis elektronik rawat jalan, yaitu : Proses Registrasi User : Admin ,Proses Login : Petugas Rekam Medis, Proses Pendaftaran Pasien : Petugas Rekam Medis, Proses Pemeriksaan Rawat Jalan Pasien : Dokter Jaga, Proses Tindakan : Petugas Rekam Medis, Proses Diagnosa : Petugas Rekam Medis, Proses Pendataan Dokter : Petugas Rekam Medis. 


\section{Entity Relationship Diagram (ERD)}

ERD dibuat untuk mempermudah analisis dan perancangan-perancangan selanjutnya. Perancangan ERD dibuat dengan cara menampilkan keseluruhan relasi antar entitas dan relasi antar dua entitas sebagai penjelas dari bagian keseluruhan entitas.

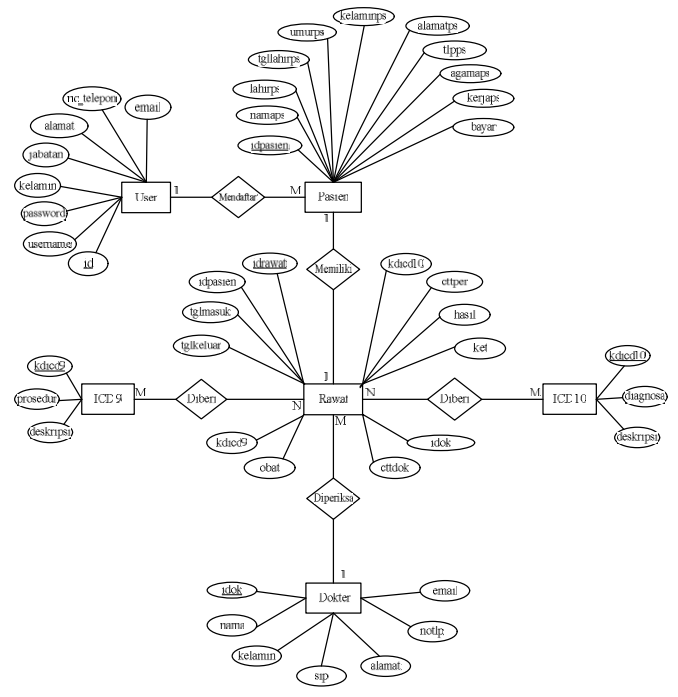

Gambar 4. Entity Relationship Diagram

\section{Perancangan Basis Data}

Perancangan basis data bertujuan untuk memudahkan atau efisiensi dalam penyimpanan, perubahan, dan pembacaan data. Untuk merancang basis data, analis perlu mendefinisikan terlebih dahulu data yang diperlukan oleh sistem. Perancangan basis data pada Sistem Informasi Rekam Medis Elektronik Rawat Jalan Berbasis Web di Klinik Gigi Bright Smiles adalah sebagai berikut:

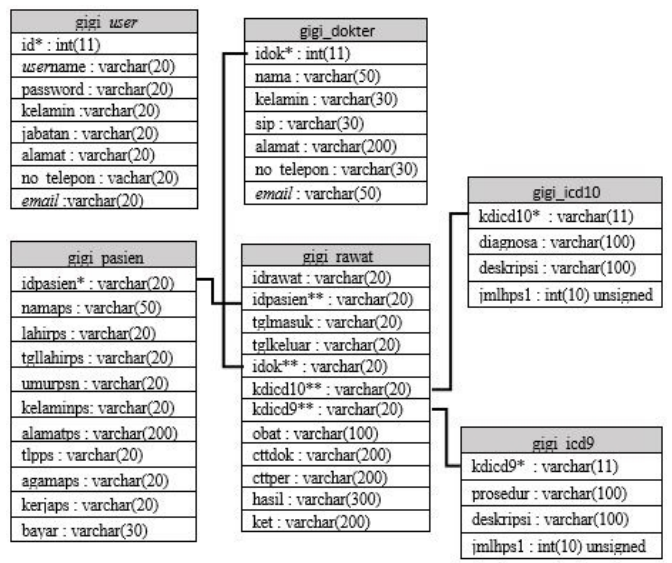

Gambar 5. Relasi Database

\section{Perancangan Dialog Antar Muka}

Perancangan dialog antar muka merupakan rancang bangun dari dialog antara pemakai sistem dengan komputer. Dialog ini dapat terdiri dari proses memasukkan (input) data ke sistem, menampilkan output informasi kepada pemakai atau dapat keduanya.

\section{1) Tampilan Halaman Login}

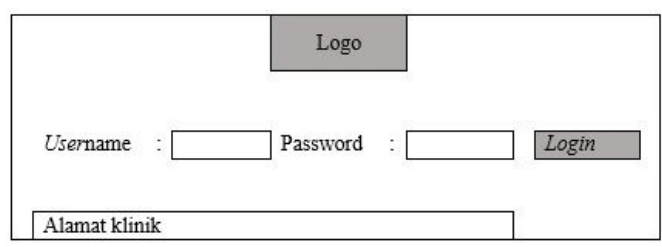

Gambar 6. Tampilan Halaman Login

\section{2) Form Pendaftaran Pasien}

\begin{tabular}{|c|c|c|c|}
\hline \multicolumn{4}{|c|}{ Form Pendaftran Pasien } \\
\hline No. RM & : & ................... AutoInput & \\
\hline Nama & : & …....... & \\
\hline Tempat lahir & : & ………... & \\
\hline Tanggal lahir & : & . & \\
\hline Umur & : & $\cdots$ & $\ldots$ \\
\hline Jenis Kelamin & : & --Pilih-- & $\nabla$ \\
\hline Alamat & $\vdots$ & $\begin{array}{l}\ldots \ldots \ldots . \\
\cdots \ldots \ldots . .\end{array}$ & $\cdots$. \\
\hline $\begin{array}{l}\text { No. telepon } \\
\text { Agama }\end{array}$ & $\vdots$ & --Pilih-- & $\nabla$ \\
\hline Pekerjaan & . & ............. & \\
\hline Pembayaran & : & --Pilih-- & $\nabla$ \\
\hline & & Tambah & \\
\hline
\end{tabular}

Gambar 7. Tampilan Form Pendaftaran Pasien 


\section{3) Form Pasien Rawat Jalan}

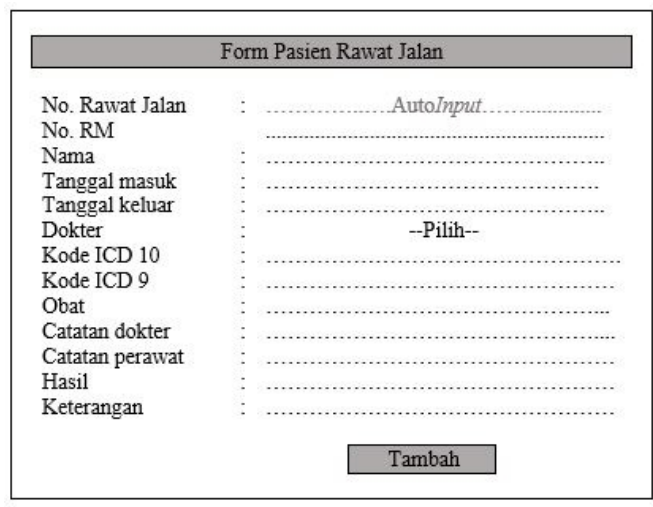

Gambar 8. Tampilan Form Pasien Rawat Jalan

\section{Tahap Implementasi}

Tahap ini merupakan kegiatan untuk mengimplementasikan rancangan yang telah disusun agar dapat diwujudkan, yaitu dengan meletakkan sistem supaya siap dioperasikan. Rancangan yang telah disusun tentunya dibuat sesuai dengan prosedurnya supaya sistem dapat dioperasikan.

\section{Tahap Penggunaan}

Setelah sistem diimplementasikan dan telah berhasil diuji coba, maka sistem dapat digunakan. Penggunaan sistem dilakukan dengan melakukan sosialisasi kepada petugas rekam medis di Klinik Gigi Bright Smiles Bali.

\section{IMPLEMENTASI SISTEM}

Implementasi sistem merupakan penerapan dan pengujian bagi sistem berdasarkan hasil analisis dan perancangan yang telah dilakukan pada bab III. Pada bab IV ini merupakan implementasi hasil rancangan menjadi sebuah Sistem Informasi Rekam Medis Elektronik Rawat Jalan Berbasis $W e b$ di Klinik Gigi Bright Smiles Bali.

\section{Antar Muka Sistem (Interface) Tampilan Halaman Login}

Untuk halaman login dapat diakses melalui alamat http://localhost/klinikgigi pada web browser maka akan tampil halaman login, kemudian user (petugas rekam medis) melakukan login dengan mengisikan username dan password. Fungsi dari halaman ini adalah untuk dapat masuk ke halaman utama dan menggunakan fasilitas yang ada didalamnya, seperti yang terlihat pada gambar berikut ini :

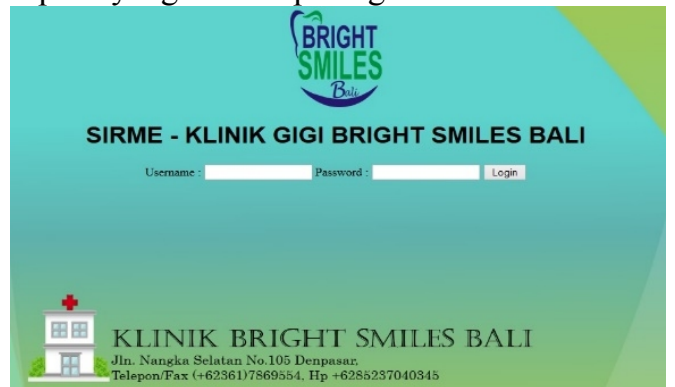

Gambar 9. Tampilan Halaman Login

\section{Tampilan Halaman Utama dan Menu}

Index halaman pada browser menunjukan halaman utama (home, profile, help, logout) dan menu (data terintegrasi, laporan, backup data dan manajemen user). Setiap menu terdiri dari beberapa submenu, yaitu:

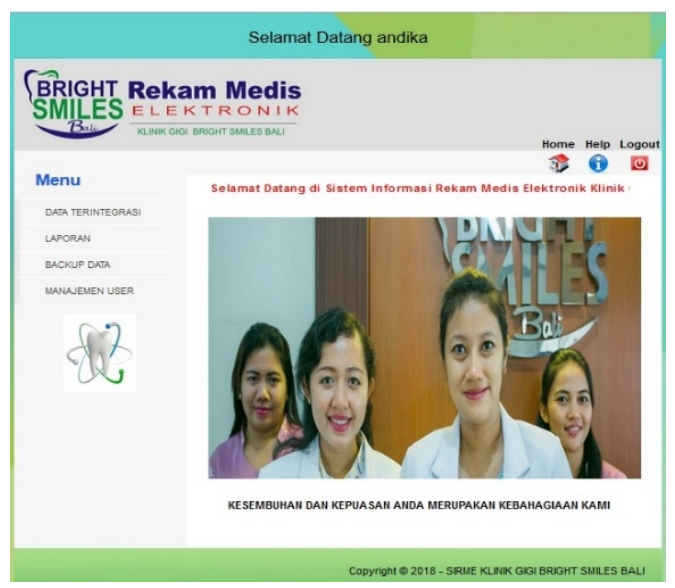

Gambar 10. Tampilan Halaman Utama

\section{Tampilan Pendaftaran Pasien}

Pada tampilan pendaftaran pasien, user (petugas rekam medis) dapat mengakses di menu data terintegrasi lalu pilih menu pendaftaran pasien, didalam menu pendaftaran pasien terdapat 3 (tiga) menu yaitu: tambah data, cari data pasien, dan menu untuk kembali ke halaman utama, dan pertiap data pasien terdapat 4 (empat) opsi yaitu: edit, detail, cetak kartu, dan hapus. Berikut ini merupakan 
tampilan untuk pendaftaran pasien Sistem Informasi Rekam Medis Elektronik di Klinik Gigi Bright Smiles Bali :

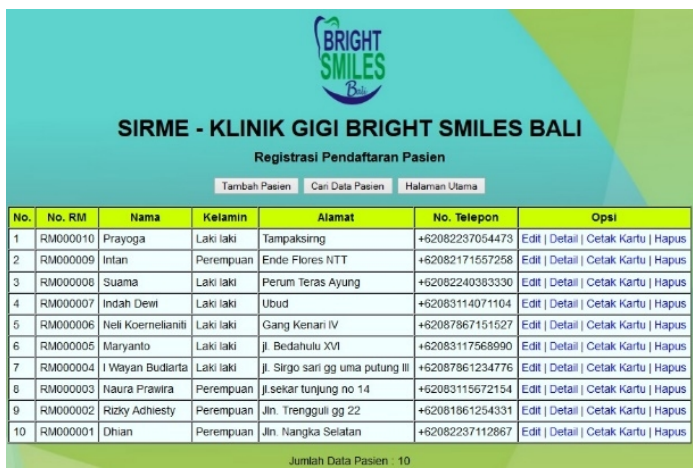

Gambar 11. TAmpilan Pendaftaran Pasien

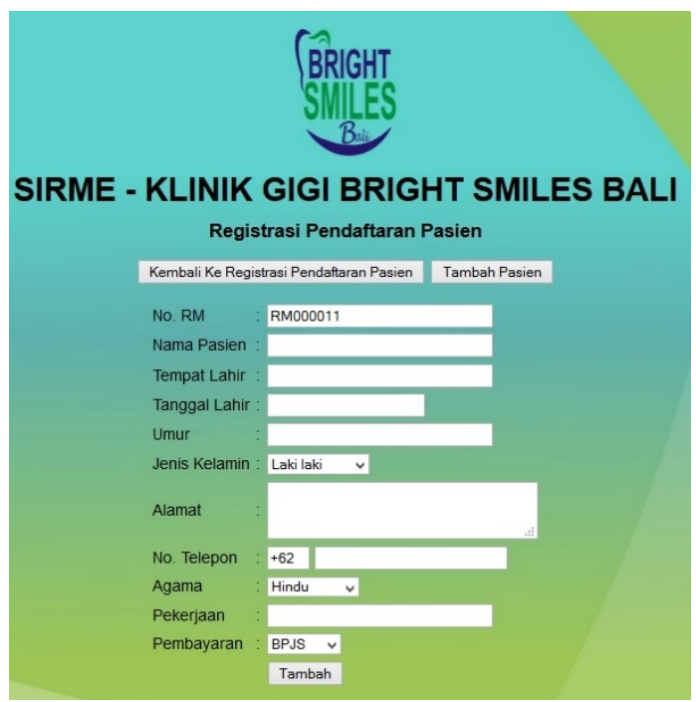

Gambar 12. Tampilan Pendaftaran Pasien

\section{Tampilan Pasien Rawat Jalan}

Pada tampilan data rawat jalan, user (petugas rekam medis) dapat mengakses di menu data terintegrasi lalu pilih menu data rawat jalan, didalam menu data rawat jalan terdapat 3 (tiga) menu yaitu: tambah data, cari data pasien rawat jalan, dan menu untuk kembali ke halaman utama, dan pertiap data pasien terdapat 3 (tiga) opsi yaitu: edit, detail, dan hapus. Berikut ini merupakan tampilan untuk data rawat jalan Sistem Informasi Rekam Medis Elektronik Rawat Jalan di Klinik Gigi Bright Smiles Bali

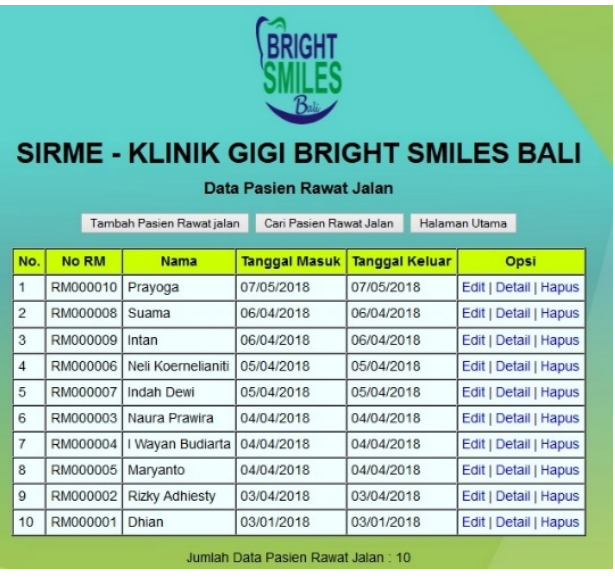

Gambar 13. Tampilan Pendaftaran Rawat Jalan

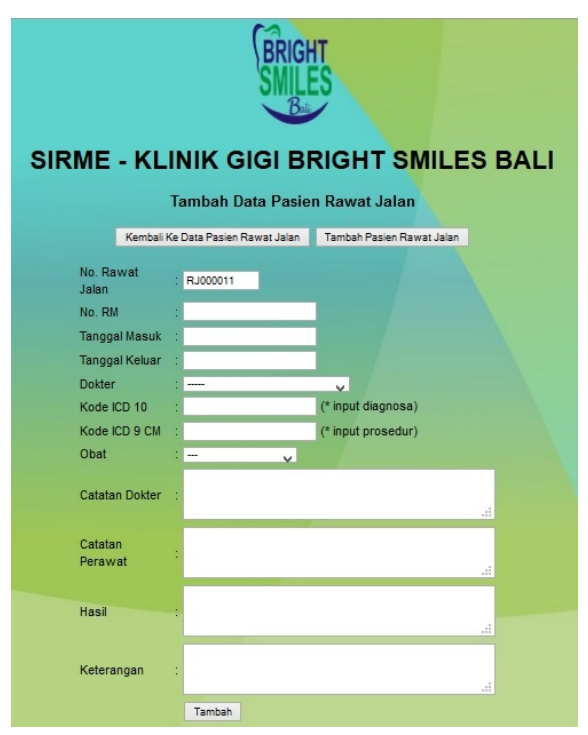

Gambar 14. Tampilan Form Rawat Jalan

\section{Tampilan Laporan}

Pada tampilan penyajian laporan, user (petugas rekam medis) dapat mengakses pada menu laporan dan pilih laporan sesuai kebutuhan, kemudian klik tombol "Cetak" untuk mencetak hasil laporan tersebut. Seperti yang terlihat pada gambar berikut ini: 
1) Rekap Data Pasien

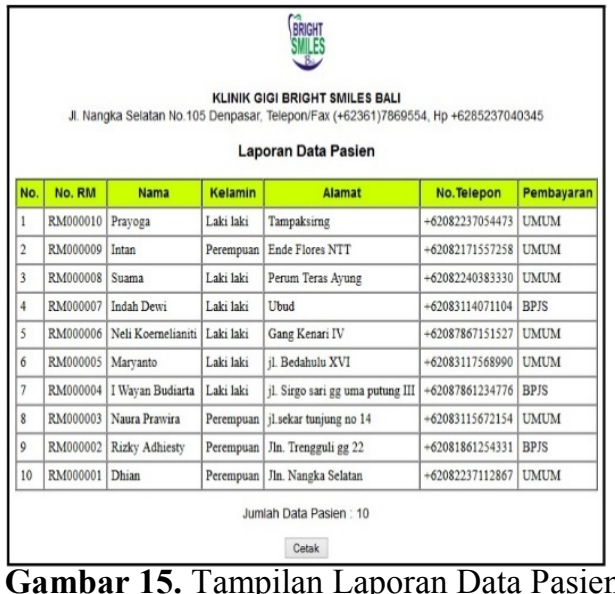

2) Rekap Data Pasien Rawat Jalan

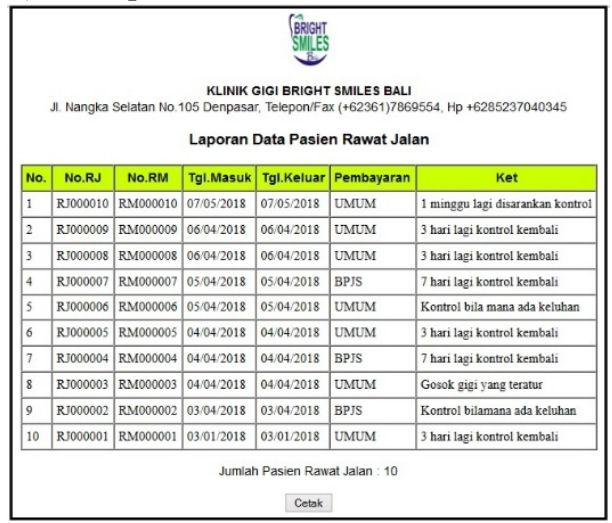

Gambar 16. Tampilan Laporan Data Pasien Rawat Jalan
3) Rekap Data 10 Besar Tindakan ICD 9

Gambar 17. Tampilan 10 Besar Tindakan ICD $9 \mathrm{CM}$

\begin{tabular}{|c|c|c|c|c|}
\hline \multicolumn{5}{|c|}{$\begin{array}{l}\text { KLINIK GIGI BRIGHT SMILES BALI } \\
\text { JI. Nangka Selatan No. } 105 \text { Denpasar, TeleponFFax (+62361)7869554, Hp +6285237040345 } \\
\text { Laporan } 10 \text { Besar Tindakan Berdasarkan ICD } 9 \text { CM }\end{array}$} \\
\hline No. & Kode ICD 9 CM & Diagnosa & Deskripsi & Jumlah \\
\hline 1 & 23.09 & Ekstraksi gigi lainnya & Ekstraksi gigi lainnya & 5 \\
\hline 2 & 23.4 & Other dental restoration & Restorasi gigi lainnya & 2 \\
\hline 3 & 23.11 & Penghapusuan sisa akar & Penghapusasn sisa akar & 1 \\
\hline 4 & 24.0 & Incision of gum or altreolar bone & Insisi permen atau tulang alreolar & 1 \\
\hline 5 & 24.7 & Application of orthodontic appliance & Penerapan alat ortodontik & 1 \\
\hline 6 & 96.54 & Dental scaling, polishing, and debridement & Dilakukan Scaling & 1 \\
\hline & & $\begin{array}{c}\text { Jumlan } 10 \text { Besar Tindakan Berdasarks } \\
\qquad \text { Cetak }\end{array}$ & kan ICD 9 CM: 6 & \\
\hline
\end{tabular}

\section{4) Rekap Data 10 Besar ICD 10}

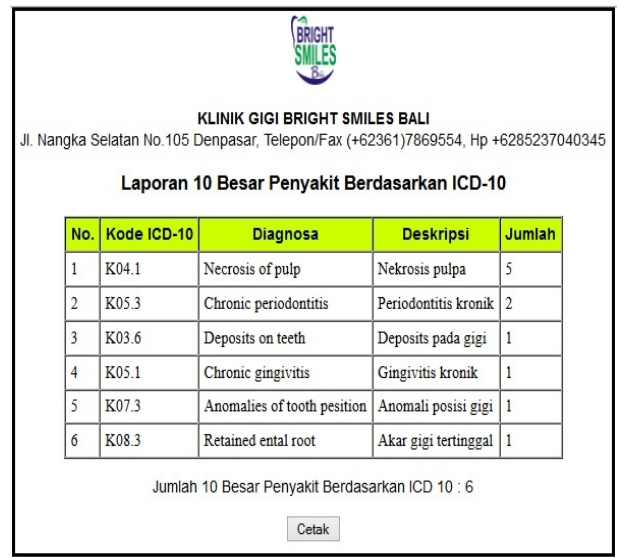

Gambar 18. Tampilan Laporan 10 Besar Diagnosa ICD 10

\section{Pengujian Blackbox}

Black box adalah menguji perangkat lunak dari segi spesifikasi fungsional tanpa menguji desain dan kode program. Pengujian dimaksudkan untuk mengetahui apakah fungsi-fungsi, masukan, dan keluaran dari perangkat lunak sesuai dengan spesifikasi yang dibutuhkan. Pengujian kotak hitam dilakukan dengan membuat kasus uji yang bersifat mencoba semua fungsi dengan memakai perangkat lunak apakah sesuai dengan spesifikasi yang dibutuhkan. 


\section{SIMPULAN}

Dari hasil penelitian dan perancangan", maka didapatkan kesimpulan sebagai berikut:

Rancangan Sistem Informasi Rekam Medis Elektronik Rawat Jalan Berbasis Web di Klinik Gigi Bright Smiles Bali dan dapat digunakan secara terkomputerisasi oleh petugas rekam medis untuk pengelolaan rekam medis. Sistem Informasi Rekam Medis Elektronik Rawat Jalan Berbasis Web di Klinik Gigi Bright Bali dapat mengurangi waktu yang awalnya 5-8 menit menjadi 2-3 pada saat registrasi dan mempercepat pencarian rekam medis pasien rawat jalan saat melakukan kontrol kesehatan gigi. Terimplementasinya Sistem Informasi Rekam Medis Elektronik Rawat Jalan Berbasis Web di Klinik Gigi Bright Smiles Bali yang meliputi aktivitas : pendaftaran pasien, pencatatan rekam medis pasien rawat jalan, pencatatan data dokter, pencarian kode ICD $9 \mathrm{CM}$, pencarian kode ICD 10. serta menghasilkan berbagai laporan-laporan dan informasi rekam medis pasien yang dibutuhkan pihak manajemen untuk pengambilan keputusan

\section{DAFTAR PUSTAKA}

[1] Akbar, A., 2015. Perancangan Sistem Informasi Rekam Medis Rawat Inap Berbasis Web di RSUD Solok Selatan. Badung : Skripsi Fakultas Ilmu Kesehatan Sains dan Teknologi Universitas Dhyana Pura Bali.

[2] Ariafrasis, U., 2011. Modul Kuliah Sistem Multimedia. Jurusan Teknik Informatika: Unikom.

[3] Arief, M. R., 2011. Pemrograman Web Dinamis Menggunakan PHP dan MySQL. Yogyakarta: Andi.

[4] Choliviana, E., Triyono, R. A. \& Sukadi, 2012. Pembuatan Sistem Informasi Pendaftaran Siswa Baru Pada Madrasah Ibtidaiyah Muhammadiyah Wonoanti III. FTI UNSA, pp. 1-9.

[5] Connolly, T. \& Carolyn, B., 2002. Database System : A Practical Approach to Design, Implementation, and Manajement, third edition. California: Addison Wesley.

[6] Depkes, D. Y., 2006. Pedoman Penyelenggaraan dan Prosedur Rekam Medis Rumah Sakit Indonesia. Jakarta: Departemen Kesehatan Republik Indonesia.

[7] Eko, 2015. Fungsi Web. [Online] Available at: http://www.fungsiklopedia.com /fungsiwebsite/ [Accessed 14 November 2017].

[8] Elcom, 2013. Seri Belajar Kilat Dreamweaver CS6. Yogyakarta: Andi Offset.

[9] Erkadius, 2011. Manajemen Informasi Kesehatan. Padang: Apikes.

[10] Fathansyah, I., 2002. Basis Data. Bandung: Informatika.

[11] Feoh, G., Linawati \& Wirastuti, N. M. A. E. D., 2015. Indeks Kepuasan Pengguna Situs Web E-Gov Di Bali Dengan Metode EUCS Dan CSI. Konferensi Nasional Sistem \& Informatika 2015.

[12] Handayani, T., 2016. Perancangan Sistem Informasi Rekam Medis Berbasis Web di Klinik Bersalin Sriati Kota Sungai Jambi Penuh - Jambi. Badung : Skripsi Fakultas Ilmu Kesehatan Sains dan Teknologi Universitas Dhyana Pura Bali.

[13] Hatta, G., 2013. Pedoman Manajemen Informasi kesehatan Disarana Pelayanan Kesehatan. Jakarta: Universitas Indonesia (UI-Press).

[14] Hozinah, 2010. Perancangan Rekam Medis Elektronik. [Online] Available at: http://studylibid.com/doc/503023/1.rekam-mediselektronik [Accessed5November 2017].

[15] Kadir, A., 2003. Pengenalan Teknologi Informasi. Yogyakarta: Andi Offset.

[16] Kemenkes, 2012. Roadmap Sistem Informasi Kesehatan (SIK) Tahun 20112014. Jakarta: Kementrian Republik Indonesia.

[17] Kenneth, E. K., 2010. Analisis dan Perancangan Sistem. Jakarta: PT. Indeks.

[18] Kristanto, A., 2008. Perancangan Sistem Informasi dan Aplikasinya. Yogyakarta: Gava Media.

[19] Kristanto, A., 2010. Kupas Tuntas PHP \& MySQL. Jam Menguasai PHP dan 
MySQL dengan Mudah \& Cepat. Klaten: Cable Book.

[20] Kustiyahningsih, Y. \& Anamsia, D. R., 2011. Pemrograman Basis Data Berbasis Web Menggunakan PHP \& MyQSL. Yogyakarta: Graha Ilmu.

[21] Ladjamuddin, 2005. Analisa dan Desain Sistem Informasi. Yogyakarta: Graha Ilmu.

[22] Ladjamuddin, 2006. Rekayasa Perangkat Lunak, cet-ke II. Yogyakarta: Graha Ilmu.

[23] Madcoms, L., 2011. Aplikasi Web Database dengan Dreamweaver dan phpMySQL. Yogyakarta: Andi Offset.

[24] Madcoms, L., 2013. Kupas Tuntas Adobe Dreamweaver CS6 dengan Pemrograman PHP \& MySQL. Yogyakarta: Andi Offset.

[25] Marlinda, L., 2004. Sistem Basis Data. Yogyakarta: Andi.

[26] Maturidi, D. A., 2012. Metode Penelitian Teknik Informatika. Yogyakarta: Deepublish.

[27] McLeod, R. \& George, P., 2008. Sistem Informasi Manajemen, Edisi 10. Jakarta: Selemba Empat.

[28] Nugroho, W. S., 2013. Pembuatan Software Rekam Medis dengan Java Netbeans + MySQL. Yogyakarta: Gava Media.

[29] O'Brien, J. A. \& Marakas, G. M., 2011. Manajemen Sistem Informasi. Jakarta: Salemba Empat.

[30] Permenkes No.269/Menkes/Per/III/2008. Rekam Medis. Jakarta: Kementrian Republik Indonesia.

[31] Permenkes No.9/Menkes/Per/I/2014. Tentang Klinik. Jakarta: Kementrian Kesehatan Republik Indonesia.

[32] Pressman, R. S. P., 2010. Pendekatan Praktisi Rekayasa Perangkat Lunak. Edisi 7. Yogyakarta: Andi.

[33] Rahardja, U., Rayeb, A. E. \& Saefullah, A., 2009. Siapa Saja Bisa Membuat Website dengan CSSdan HTML. Yogyakarta: Andi.

[34] Rosa, A. \& Shalauddin, M., 2011. Modul Pembelajaran Rekayasa Perangkat Lunak (Terstruktur dan Berorientasi Objek). Bandung: Modula.
[35] Rosa, A. \& Shalauddin, M., 2013. Rekayasa Perangkat Lunak Terstruktur Dan Berorientasi Objek. Bandung: Informatika.

[36] Rustiyanto, E., 2010. Sistem Informasi Manajemen Rumah Sakit yang Terintegrasi. Yogyakarta: Gosyen Publishing.

[37] Saputra, A., Subagio, R. T. \& Saluky, 2012. Membagun Aplikasi E-Library Untuk Panduan Skrips. Jakarta: PT. ELEX Media Komputindo.

[38] Subhan, M., 2012. Analisa Perancangan Sistem. Jakarta: Lentera Ilmu Cendekia.

[39] Sugiyono, 2012. Memahami Penelitian Kualitatif. Bandung: Alfabeta.

[40] Sugiyono, 2013. Metode Penelitian Pendidikan ( Pendekatan Kuantitatif, Kualitatif, dan R\&D). Bandung: Alfabeta.

[41] Sukamto, R. A. \& Shalahuddin, M., 2011. Modul Pembelajaran Rekayasa Perangkat Lunak. Bandung: Andi Offset.

[42] Supardi, Y. I., 2013. Semua Bisa Menjadi Programmer Visual Basic 2010 case study. Jakarta: PT. ELEX Media Komputindo.

[43] Supriyanto, A., 2005. Pengantar Teknologi Informasi. Jakarta: Salemba Infotek.

[44] Sutabri, T. S. M., 2004. Analisa Sistem Informasi Edisi Pertama. Yogyakarta: Andi.

[45] Sutarman, 2007. Membangun Aplikasi Web Dengan PHP \& MySQL. Yogyakarta: Graha Ilmu.

[46] Sutarman, 2012. Membangun Aplikasi Berbasis Web dengan PHP dan ASP. Malang: Gava Media.

[47] UU RI No. 29 2014. Tentang Praktik Kedokteran. Jakarta: Presiden Republik Indonesia

[48] Wahana, K., 2010. Panduan Belajar MySQL Database Server. Jakarta Selatan: Media Kita.

[49] Wicaksono, A. S., 2011. Pemrograman Web Aplikatif dengan Java. Jakarta: PT.ELEX Media Komputindo. 